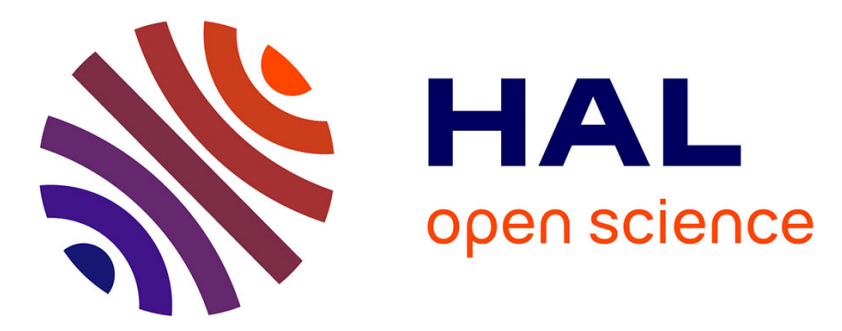

\title{
Differential regulation of skeletal muscle protein turnover by insulin and IGF-I after bacteremia
}

Thomas C. Vary, Dominique Dardevet, Jean Grizard, Laure Voisin, Caroline Buffière, Philippe Denis, Denis Breuillé, Christiane Obled

\section{- To cite this version:}

Thomas C. Vary, Dominique Dardevet, Jean Grizard, Laure Voisin, Caroline Buffière, et al.. Differential regulation of skeletal muscle protein turnover by insulin and IGF-I after bacteremia. AJP Endocrinology and Metabolism, 1998, 275 (4), pp.E584-E593. hal-02687327

\section{HAL Id: hal-02687327 https://hal.inrae.fr/hal-02687327}

Submitted on 1 Jun 2020

HAL is a multi-disciplinary open access archive for the deposit and dissemination of scientific research documents, whether they are published or not. The documents may come from teaching and research institutions in France or abroad, or from public or private research centers.
L'archive ouverte pluridisciplinaire HAL, est destinée au dépôt et à la diffusion de documents scientifiques de niveau recherche, publiés ou non, émanant des établissements d'enseignement et de recherche français ou étrangers, des laboratoires publics ou privés. 
Thomas C. Vary, Dominique Dardevet, Jean Grizard, Laure Voisin, Caroline

Buffiere, Phillipe Denis, Denis Breuille and Christiane Obled

Am J Physiol Endocrinol Metab 275:584-593, 1998.

You might find this additional information useful...

This article cites 35 articles, 19 of which you can access free at:

http://ajpendo.physiology.org/cgi/content/full/275/4/E584\#BIBL

This article has been cited by 13 other HighWire hosted articles, the first 5 are:

Acute alcohol intoxication increases atrogin-1 and MuRF1 mRNA without increasing proteolysis in skeletal muscle

T. C. Vary, R. A. Frost and C. H. Lang

Am J Physiol Regulatory Integrative Comp Physiol, June 1, 2008; 294 (6): R1777-R1789.

[Abstract] [Full Text] [PDF]

Regulation of muscle protein synthesis during sepsis and inflammation

C. H. Lang, R. A. Frost and T. C. Vary

Am J Physiol Endocrinol Metab, August 1, 2007; 293 (2): E453-E459.

[Abstract] [Full Text] [PDF]

IGF-I stimulates protein synthesis in skeletal muscle through multiple signaling pathways during sepsis

T. C. Vary

Am J Physiol Regulatory Integrative Comp Physiol, February 1, 2006; 290 (2): R313-R321.

[Abstract] [Full Text] [PDF]

Indinavir alters regulators of protein anabolism and catabolism in skeletal muscle

L. Q. Hong-Brown, A. M. Pruznak, R. A. Frost, T. C. Vary and C. H. Lang

Am J Physiol Endocrinol Metab, September 1, 2005; 289 (3): E382-E390.

[Abstract] [Full Text] [PDF]

Proteasome activity is altered in skeletal muscle tissue of tumour-bearing rats a leucine-rich diet

G Ventrucci, M A R Mello and M C C Gomes-Marcondes

Endocr. Relat. Cancer, December 1, 2004; 11 (4): 887-895.

[Abstract] [Full Text] [PDF]

Medline items on this article's topics can be found at http://highwire.stanford.edu/lists/artbytopic.dtl on the following topics:

Oncology .. Protein Degradation

Oncology .. Protein Synthesis

Biochemistry .. Insulin-Like Growth Factor I

Medicine .. Insulin

Microbiology .. Escherichia Coli

Physiology .. Rats

Updated information and services including high-resolution figures, can be found at:

http://ajpendo.physiology.org/cgi/content/full/275/4/E584

Additional material and information about AJP - Endocrinology and Metabolism can be found at:

http://www.the-aps.org/publications/ajpendo

This information is current as of September 3, 2010 .

AJP - Endocrinology and Metabolism publishes results of original studies about endocrine and metabolic systems on any level of organization. It is published 12 times a year (monthly) by the American Physiological Society, 9650 Rockville Pike, Bethesda MD 20814-3991. Copyright () 1998 by the American Physiological Society. ISSN: 0193-1849, ESSN: 1522-1555. Visit our website at http://www.the-aps.org/. 


\title{
Differential regulation of skeletal muscle protein turnover by insulin and IGF-I after bacteremia
}

\author{
THOMAS C. VARY, DOMINIQUE DARDEVET, JEAN GRIZARD, LAURE VOISIN, \\ CAROLINE BUFFIERE, PHILLIPE DENIS, DENIS BREUILLE, AND CHRISTIANE OBLED \\ Laboratoire d'Etude du Metabol isme Azote, Institut National de la Recherche Agronomique, \\ Theix 63122 Ceyrat; Clintec Technologies, 78148 Velizy Cedex, France; and Department of Cellular \\ and Molecular Physiology, Penn State University College of Medicine, Hershey, Pennsylvania 10733
}

\begin{abstract}
Vary, Thomas C ., Domi nique Dardevet, J ean Grizard, Laure Voisin, Caroline Buffiere, Phillipe Denis, Denis Breuille, and Christiane Obled. Differential regulation of skeletal muscle protein turnover by insulin and IGF-I after bacteremia. Am. J. Physiol. 275 (Endocrinol. Metab. 38): E584-E593, 1998.-Skeletal muscle catabolism is a characteristic metabolic response to sepsis. We investigated the ability of physiological insulin (2 nM) or insulin-like growth factor I (IGF-I, $10 \mathrm{nM})$ concentrations to modify protein metabolism during incubation of epitrochlearis 2, 6, or 15 days after injection of live Escherichia coli. On days 2 and 6 postinfection, skeletal muscle exhibited an exacerbated negative protein balance resulting from both an inhibition in protein synthesis (25\%) and an enhanced proteolysis (90\%) compared with controls. By day 15 postinfection, protein balance in infected rats was significantly improved compared with either day 2 or 6 . At this time, protein synthesis was augmented and protein degradation was decreased in infected rats relative to day 6 . Insulin or IGF-I stimulated protein synthesis in muscles from septic and control rats in vitro to the same extent at each time point examined. The ability of insulin or IGF-I to limit protein degradation was severely blunted $48 \mathrm{~h}$ after infection. On day 6 postinfection, the effect of insulin or IGF-I to inhibit proteolysis was more pronounced than on day 2. Incubation with IGF-I limited proteolysis to a greater extent than insulin on both days in infected but not control rats. By day 15, insulin diminished proteolysis to the same extent as in controls. The results suggest that injection of bacteria causes fundamental derangements in protein metabolism that persist for days after infection.
\end{abstract}

epitrochlearis; protein synthesis; proteolysis; insulin-like growth factor I; sepsis

SEVERE INFECTION initiates a cascade of events that leads to a loss of body proteins, reflected by massive excretion of urea and large negative nitrogen balances. Nitrogen losses equivalent to 5-17\% of the total body protein are observed in septic patients despite adequate nutritional support. Much of this loss of body protein originates from skeletal muscle. Catabolism of skeletal muscle proteins results in muscle wasting and fatigue, which are well-recognized features of the host's response to sepsis. The loss of protein in skeletal muscle is a consequence of an imbalance between protein synthesis and protein degradation. Ultimately, the negative protein balance in skeletal muscle results

\footnotetext{
The costs of publication of this article were defrayed in part by the payment of page charges. The article must therefore be hereby marked "advertisement" in accordance with 18 U.S.C. Section 1734
} solely to indicate this fact. from the complex interactions among hormones, amino acid fluxes, and mediators of the septic response that shift the dynamic balance between protein synthesis and proteolysis. The ability of physiological concentrations of anabolic hormones to modulate protein balances in skeletal muscle during chronic sepsis remains unresolved.

Although parenteral nutrition has become an important therapy in septic patients, it is insufficient al one to prevent the loss of skeletal muscle protein. Thus additional regimens, such as use of anabolic agents, have been proposed to attenuate the loss of muscle protein during sepsis (34). The major anabolic hormones promoting accretion of skeletal muscle proteins include insulin, growth hormone $(\mathrm{GH})$, and insulin-like growth factor I (IGF-I). Insulin enhances the global rate of protein synthesis and decreases the rate of protein degradation in skeletal muscle under a variety of conditions. Administration of insulin to injured (35) or septic patients (14) reduces whole body net protein catabolism. However, the ability of insulin to enhance protein synthesis is variable in skel etal muscle during sepsis. During the immediate postinfection period (up to $48 \mathrm{~h}$ ), insulin stimulates protein synthesis (11, 12, 29). However, during chronic (5 day) intra-abdominal sepsis, insulin was without effect in augmenting skeletal muscle protein synthesis (16). In contrast to protein synthesis, protein degradation in skeletal muscle consistently shows a relative resistance to insulin during the immediate posttrauma period (29) or during acute $(16 \mathrm{~h})$ peritonitis $(11,12)$.

Like insulin, GH promotes nitrogen retention and improves nitrogen balance in a variety of catabolic conditions, including burn and postoperative surgical patients (for review, see Ref. 34). However, septic patients show a relative $\mathrm{GH}$ resistance (5). The anabolic actions of $\mathrm{GH}$ on protein metabolism in skeletal muscle are believed to be mediated indirectly through GH-stimulated secretion of another hormone, IGF-I. In sepsis, there is an uncoupling of the normal GH/IGF-I axis, so that although $\mathrm{GH}$ concentrations are elevated, IGF -I concentrations are generally depressed $(3,5,19)$. The suppression of IGF-I concentrations is thought to limit the anabolic actions of $\mathrm{GH}$ in sepsis.

Consequently, IGF-I may be of moreimportance than $\mathrm{GH}$ in improving nitrogen balance in skeletal muscle during sepsis. In this regard, systemically administered IGF -I stimulates weight gain and protein synthesis in normal rats (13), increases lean body mass during starvation (20) or diabetes (28), and attenuates protein loss during glucocorticoid-induced cachectic states (27). 
Chronic IGF-I administration has been reported to improve nitrogen balance in rats injected with endotoxin (8). The mechanisms responsible for the improvement in nitrogen balance after IGF-I in endotoxintreated rats have not been elucidated. J urasinski and Vary (18) reported that I GF -I stimulates protein synthesis in skel etal muscle from chronic septic rats during in vitro perfusion, suggesting that some of the proteinsparing effect of IGF-I may be mediated through enhanced rates of protein synthesis. Likewise, IGF-I is thought to enhance protein accretion in muscle by enhancing protein synthesis in normal humans (10, 22). In contrast to protein synthesis, there are no reports concerning the effect of I GF -I on protein degradation in skeletal muscle during sepsis. However, IGF-I attenuates the stimulation of proteolysis induced by thermal injury (9).

The purpose of the present study was to compare and contrast the ability of insulin or IGF-I to modulate protein synthesis and degradation in the epitrochlearis after injection of live Escherichia coli. By use of the incubated muscle preparation, effects of insulin or IGF-I on protein synthesis and degradation can be examined independently of alterations in plasma concentrations of substrates or other hormones induced by in vivo injection of either hormone $(24,25)$. We established the effects of these two anabolic hormones on skeletal muscle protein metabolism during the anorexic ( 2 days postinfection), hypermetabolic ( 6 days postinfection), and recovery (15 days postinfection) phases of the response to a severe infection.

\section{MATERIALS AND METHODS}

Experimental design. Male Sprague-Dawley rats (250-300 g) were individually housed in wire-bottom cages in a temperature-controlled environment $\left(22-23^{\circ} \mathrm{C}\right)$ with a $12: 12$-h lightdark cycle. During a 6-day period of acclimatization before injection of bacteria, all rats had free access to water and food ad libitum. The diet consisted of a semisynthetic laboratory diet containing $12 \%$ protein and previously shown to sustain normal growth in rats (1).

Two groups of animals, control (group 1) and infected (group 2), were used to investigate the effect of sepsis on protein synthesis and protein degradation. The infected group was produced by an injection of live $\mathrm{E}$. coli $(0.6-0.9 \times$ $10^{9}$ colony forming units/rat) into the tail vein as previously described $(1,2,33)$. Control rats received an equal volume of saline. After injection of bacteria, a hypermetabolic, sepsislike condition devel ops as evidenced by leukocytosis, an acute phase response, hyperlactatemia, low-grade fever, weight loss, and muscle atrophy $(1,2,31,33)$. Bacteremia is maintained for at least $48 \mathrm{~h}$ after injection of $\mathrm{E}$. coli (33). The mortality rate was $20 \%$ for animals injected with bacteria. No animals injected with saline expired. Because injection of live $E$. coli causes anorexia in this model, control rats were pair fed to the septic rats by estimating food intake based on previous studies and correcting the daily intake with the actual food consumption of the septic group $(1,33)$. Animals were offered food twice daily at 9:00 AM and 5:00 PM. All rats were fasted overnight before sampling of muscles for in vitro incubations. Animals were weighed on a daily basis. The experiments were carried out with the approval of animal care and use committees at both institutions.
Incubations of epitrochlearis muscles. Epitrochlearis muscles were incubated in vitro as described previously $(6,7$, $24,25,29,31,33)$. The epitrochlearis was chosen for examination of protein turnover after injection of bacteria because previous reports have provided evidence that sepsis preferentially affects protein metabolism in muscles composed of mixed fast-twitch fibers $(4,26,32)$. On the day of the experiment, rats were anesthetized with pentobarbital sodium (50 mg/kg body wt). The skin on each of the forearms was removed. The epitrochlearis muscles were excised intact and immediately placed in Krebs-Henseleit bicarbonate buffer. The muscles were quickly rinsed and transferred to plastic tubes containing $2 \mathrm{ml}$ of buffer. The tubes were capped and immediately oxygenated. One muscle from each rat was incubated under basal conditions (no hormones) while the contralateral muscle was incubated in the presence of insulin or IGF-I. Because incubations were performed on different days, muscles from control and infected rats incubated under basal conditions were al ways performed to allow for comparisons from one experiment to the next.

E pitrochlearis muscles were first preincubated for $30 \mathrm{~min}$. After the preincubation period, muscles were transferred to fresh medium ( $2 \mathrm{ml}$ ) and incubated for a further $180 \mathrm{~min}$, with a change of buffer every $60 \mathrm{~min}$. During the final $60 \mathrm{~min}$ of the incubation period, the buffer was supplemented with $0.5 \mathrm{mM} \mathrm{L}-\left[{ }^{14} \mathrm{C}\right]$ phenylalanine $(0.15 \mu \mathrm{Ci} / \mathrm{ml})$. At the end of the incubation, muscles were removed from the incubation buffer, trimmed of connective tissue, immersed into $2 \mathrm{ml}$ of ice-cold $10 \%$ (wt/vol) TCA, and weighed. The incubation medium was frozen and stored at $-20^{\circ} \mathrm{C}$ for analysis of tyrosine and the specific radioactivity of phenylalanine.

The Krebs-Henseleit bicarbonate buffer consisted of 120 $\mathrm{mM} \mathrm{NaCl}, 4.8 \mathrm{mM} \mathrm{KCl}, 25 \mathrm{mM} \mathrm{NaHCO}, 2.5 \mathrm{mM} \mathrm{CaCl}_{2}, 1.2$ $\mathrm{mM} \mathrm{KH}_{2} \mathrm{PO}_{4}$, and $1.2 \mathrm{mM} \mathrm{M} \mathrm{gSO}_{4}$ (pH 7.4) supplemented with $5 \mathrm{mM}$ glucose, $5 \mathrm{mM}$ HEPES, 0.1\% (wt/vol) BSA, $0.17 \mathrm{mM}$ leucine, $0.20 \mathrm{mM}$ valine, and $0.10 \mathrm{mM}$ isoleucine. Muscles were incubated at $37^{\circ} \mathrm{C}$ under an atmosphere of $95 \% \mathrm{O}_{2-}^{-}$ $5 \% \mathrm{CO}_{2}$. In some experiments, insulin (Novo Pharmaceuticals, Denmark) or IGF-I (Preprotech, France) was added at the concentrations described in the figures and tables. Insulin or IGF-I was diluted fresh the day of the experiment in Krebs-Henseleit buffer.

Protein synthesis. Rates of protein synthesis were estimated by the incorporation of radioactive phenylalanine into muscle protein. Muscles were homogenized in $2 \mathrm{ml}$ of $10 \%$ TCA using a Polytron PT 10 set at $60 \%$ of maximal speed. The homogenate was centrifuged at $10,000 \mathrm{~g}$ for $10 \mathrm{~min}$ at $4^{\circ} \mathrm{C}$. The supernatant was decanted, and the pellet was washed three additional times with $10 \%$ TCA to remove any acidsoluble radioactivity. The resulting pellet was dissolved in $1 \mathrm{~N}$ $\mathrm{NaOH}$ and incubated at $37^{\circ} \mathrm{C}$ for a minimum of $30 \mathrm{~min}$. Aliquots were assayed for protein using the bicinchoninic acid procedure (Pierce Chemicals, Rockford, IL) per the manufacturer's procedure with crystalline BSA as a protein standard. Another aliquot was assayed for radioactivity by liquid scintillation spectrophotometry using corrections for quenching (disintegrations/min). Rates of protein synthesis, expressed as nanomoles of phenylalanine incorporated per hour per milligram of protein, were calculated by dividing the amount of radioactivity incorporated into muscle protein over a 1-h period by the specific radioactivity of the phenylalanine in the incubation medium.

Protein degradation. Rates of protein degradation were measured by the accumulation of tyrosine in the incubation medium as described previously $(6,7,29,33)$. Because tyrosine is neither synthesized nor metabolized by muscle, except for use by protein synthesis, the release of tyrosine 
from muscle into the incubation medium reflects net protein balance. Total protein degradation was estimated simultaneously with the rate of protein synthesis as the sum of the accumulation of tyrosine in the incubation buffer over a 1-h period plus the amount of tyrosine equivalents incorporated into protein via protein synthesis during the same time interval. To obtain the amount of tyrosine incorporated into mixed muscle proteins, we multiplied the values for incorporation of radioactive phenylalanine into protein by the molar ratio of tyrosine to phenylalanine in mixed proteins from skeletal muscle $(0.77)(6,7,29)$. Thus values for tyrosine equivalents incorporated into mixed muscle protein could be estimated for each individual muscle. Tyrosine in the incubation medium was measured fluorometrically as described previously $(6,7)$.

Statistics. The experimental data for each condition are summarized as means $\pm \mathrm{SE}$. The statistical evaluation of the data was performed using ANOVA to test for overall differences among groups, followed by the Sidak test for multiple comparisons to determine significance between means only when theANOVA indicated a significant difference among the group means (31). Differences among means were considered significant when $\mathrm{P}<0.05$.

\section{RESULTS}

Incubation conditions for assessing effects of insulin or IGF-I on rates of protein synthesis and degradation. Previous studies examining control of protein metabolism by hormones in epitrochlearis muscle incubated in vitro have utilized either young, rapidly growing rats $(24,25)$ or old rats that display retarded growth rates and a resistance to the effects of insulin or IGF-I on protein metabolism (6). It was therefore necessary to establish the responsiveness of incubated epitrochlearis muscle to insulin or IGF-I from 250- to 300-g rats used in the present study. Epitrochlearis muscles from $300-g$ rats were incubated for various periods of time with buffer supplemented with $30 \mathrm{nM}$ insulin to establish a time course for studying the effects of insulin on protein turnover (Table 1). Protein synthesis was increased, although not significantly during the 1st $h$ of incubation with buffer containing insulin. Thereafter, the rate of protein synthesis remained significantly elevated compared with values obtained in muscles incubated in the absence of the hormone. In contrast to

Table 1. Effect of time of incubation on rates of protein synthesis and protein degradation in rat epitrochlearis muscleincubated in vitro in presence or absence of insulin

\begin{tabular}{|c|c|c|c|c|}
\hline \multirow{2}{*}{$\begin{array}{l}\text { Incubation } \\
\text { Interval, } \\
\text { min }\end{array}$} & \multicolumn{2}{|c|}{$\begin{array}{l}\text { Protein Synthesis, } \\
\text { nmol Phe incorp } \cdot \mathrm{h}^{-1} \cdot \mathrm{mg} \\
\text { protein }^{-1}\end{array}$} & \multicolumn{2}{|c|}{$\begin{array}{c}\text { Proteolysis, } \\
\text { nmol Tyr released } \cdot \mathrm{h}^{-1} \cdot \mathrm{mg} \\
\mathrm{protein}^{-1}\end{array}$} \\
\hline & -Insulin & +Insulin & -Insulin & +Insulin \\
\hline $\begin{array}{c}30-90 \\
90-150 \\
150-210\end{array}$ & $\begin{array}{l}0.318 \pm 0.019 \\
0.266 \pm 0.025 \\
0.262 \pm 0.019\end{array}$ & $\begin{array}{l}0.429 \pm 0.017 * \\
0.469 \pm 0.023 \dagger\end{array}$ & $\begin{array}{l}1.33 \pm 0.06 \\
1.39 \pm 0.04 \\
1.64 \pm 0.09\end{array}$ & $\begin{array}{l}1.33 \pm 0.19 \\
1.25 \pm 0.03 \\
1.29 \pm 0.08 \ddagger\end{array}$ \\
\hline
\end{tabular}

Values are means \pm SE for 8 muscles in each group at each time interval. Muscles were incubated for intervals up to $3.5 \mathrm{~h}$. $\left.{ }^{14} \mathrm{C}\right]$ phenylalanine was included during final hour of incubation. Insulin was included in buffer at a concentration of $30 \mathrm{nM}$. Rates of protein synthesis and protein degradation were calculated as described in METHODS. *P $<0.001 ; \uparrow P<0.005 ; \ddagger P<0.05$ vs. - insulin. protein synthesis, only during the 3rd $\mathrm{h}$ of incubation was a significant difference in protein degradation between muscles incubated with and without insulin observed. The effect of insulin was to prevent the enhanced rates of proteolysis observed during the $3 r d h$ of incubation in the absence of the hormone. Because 3 $h$ of incubation were required for an effect of insulin on protein degradation to be observed, all subsequent studies were performed during the 3rd $\mathrm{h}$ of incubation. Over the same time interval, rates of protein synthesis remained constant whether in the presence or absence of insulin. These observations are consistent with previous reports using epitrochlearis muscles weighing less than the ones used in the present study $(24,25)$.

The sensitivity of protein synthesis and protein degradation to various concentrations of insulin or IGF-I was determined to establish the minimal concentration of insulin or IGF-I necessary to elicit both a maximal stimulation of protein synthesis and a maximal inhibition of protein degradation. Protein synthesis was significantly increased at the lowest insulin concentration $(0.5 \mathrm{nM})$ tested and was maximally stimulated at an insulin concentration of $2 \mathrm{nM}$ (Fig. 1, top). The rate of protein degradation was maximally inhibited at 2 $\mathrm{nM}$ as well. Therefore the maximal responsiveness of both protein synthesis and protein degradation was achieved at $2 \mathrm{nM}$ insulin. All subsequent studies involving insulin were performed with this concentration.

A similar approach was used to establish the minimal concentration of IGF-I necessary to elicit its maximal effect on protein synthesis and protein degradation (Fig. 1, bottom). Protein synthesis was stimulated with a concentration of $3 \mathrm{nM}$ IGF-I, with maximal stimulation occurring at $10 \mathrm{nM}$. Likewise, protein degradation was maximally decreased by $10 \mathrm{nM}$ IGF-I. The concentration of IGF-I (10 nM) necessary to elicit the maximal responsiveness for protein synthesis was similar to that observed for rapidly growing young rats $(6,18)$. All subsequent studies involving IGF-I were performed using $10 \mathrm{nM}$ IGF-I.

Effect of infection on protein catabolism measured in incubated epitrochlearis. Injection of $\mathrm{E}$. coli caused a profound anorexia that lasted $\sim 2$ days (Fig. 2). Thereafter, food consumption increased in infected rats and returned to values observed before injection of bacteria. On day 14 postinfection, food was removed at $\sim 5: 00$ PM. Therefore, food consumption on that day reflected what the animals consumed during the day. Also shown is the food consumption in control animals pair fed to match the food intake of the infected rats.

Growth rates were similar in both groups before infection (data not shown). Figure 3 shows the growth rates of control and infected rats over the course of the experimental period. Control rats lost weight for $72 \mathrm{~h}$ after beginning the pair-feeding regimen. Then, as food consumption returned toward normal, control rats began to gain weight and continued to grow throughout the remainder of the experimental period. Infected rats lost weight during the first $72 \mathrm{~h}$ after injection of the bacteria. In contrast to pair-fed control rats, infected rats did not gain weight from 3 to 7 days postinfection, 


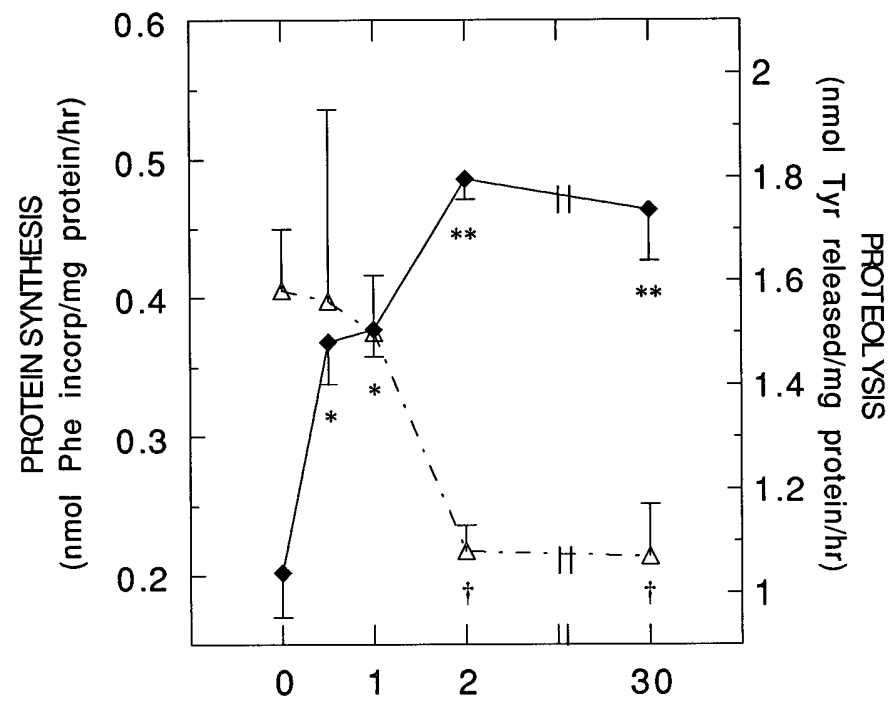

INSULIN CONCENTRATION (nM)

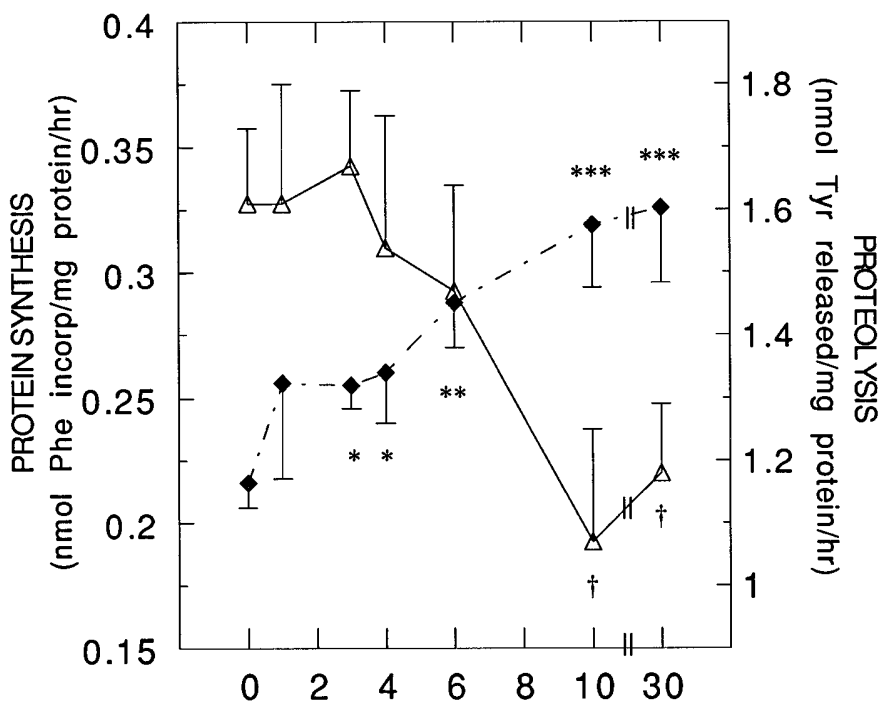

IGF-I CONCENTRATION (nM)

Fig. 1. Effect of insulin (top) or insulin-like growth factor I (IGF-I bottom) on rates of protein synthesis and protein degradation in rat epitrochlearis muscle incubated in vitro. E pitrochlearis muscles from control rats were excised and incubated in vitro as described in MATERIALS AND METHODS. Rates of protein synthesis were measured by incorporation of $\left[{ }^{14} \mathrm{C}\right]$ phenylalanine (Phe) into muscle proteins. Protein degradation was estimated simultaneously with rates of protein synthesis as sum of net change in amount of tyrosine (Tyr) in incubation buffer over $1 \mathrm{~h}+$ amount of tyrosine equivalents incorporated by protein synthesis during same time interval. The latter was calculated from measured incorporation of radioactive phenylalanine into protein, by using a conversion factor of $0.77 \mathrm{nmol}$ of tyrosine incorporated into muscle proteins per nanomole of phenylalanine. Values shown are means $\pm \mathrm{SE}$. Insulin, $\mathrm{n}=3-16$ muscles at each concentration; IGF-I, $\mathrm{n}=4-5$ at each concentration. Protein synthe sis: $* \mathrm{P}<0.05$; ** $\mathrm{P}<0.005$; *** $\mathrm{P}<0.001$ vs. 0 insulin or IGF-I. Protein degradation: $\uparrow P<0.05$ vs. 0 insulin or IGF-I.

even though food consumption increased. Then, beginning approximately on day 8 , the body weight of the infected rats began to rise and continued to do so for the remainder of the experimental period. However, the weight of the infected rats never reached that of the pair-fed control rats. Thus, despite equal food intake,

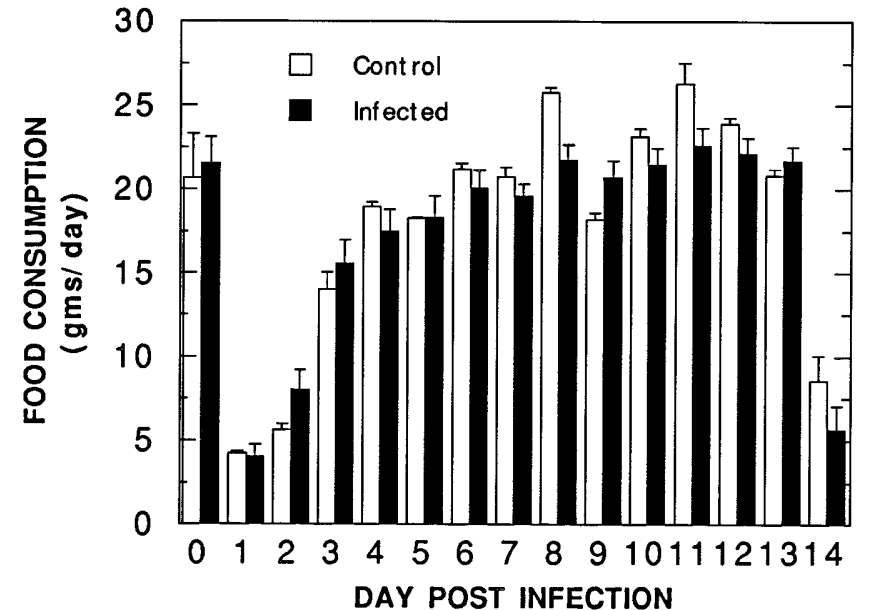

Fig. 2. Food consumption after injection of E. coli. Amount of food consumed by control and septic rats was measured twice (9:00 AM and 5:00 PM) daily. Amount of food consumed was taken as difference between weight of food presented and amount remaining. Septic group was offered food ad libitum throughout experimental period. Amount of laboratory food presented to pair-fed control group was adjusted accordingly, so that food intake was limited to equalize consumption relative to sepsis group. On last day (day 14), food was withdrawn at 3:00 PM. Therefore food consumption for that day represents only the amount of food eaten during day. Values shown are means \pm SE for 9-25 animals in each group at each time.

the body weight of the infected rats remained depressed relative to control rats over the entire course of the experimental period.

The weight of the epitrochlearis muscle in pair-fed control and infected rats is shown in Fig. 4 (top). The weight of the epitrochlearis muscle was significantly decreased 24,31 , and $20 \%$ in the infected rats compared with muscles from control rats on days 2,6 , and 15 postinfection, respectively. Over the period from days 6 to 15 postinfection, the weight of the epitrochlearis increased significantly by $50 \%(P<0.01)$ in infected rats, corresponding with the increase in the body weight over the same time period. Similar find-

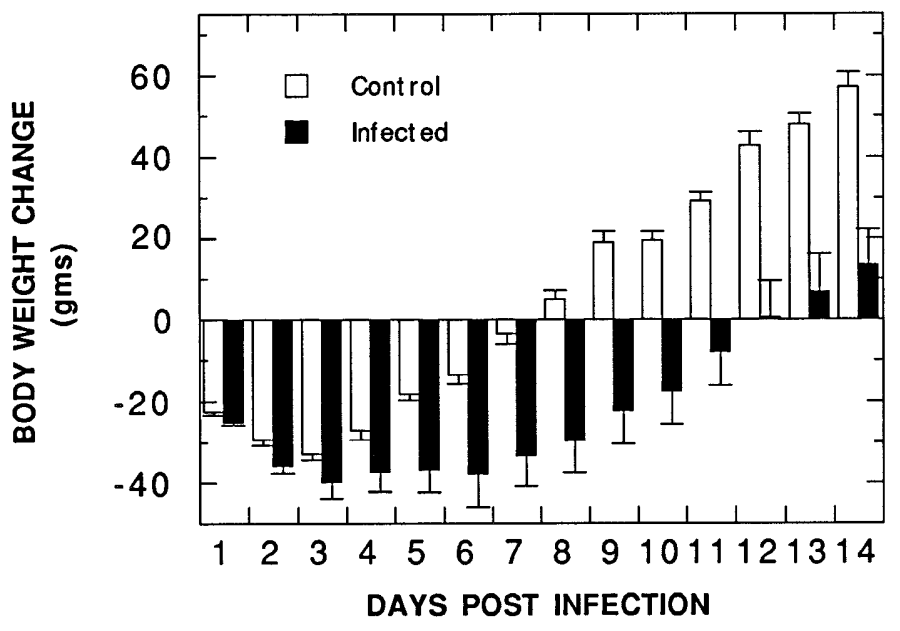

Fig. 3. Cumulative weight changes in infected and pair-fed control rats. Infected and pair-fed control rats described in Fig. 2 were weighed daily before morning meal. Differences in weight from day 0 are plotted. Values shown are means \pm SE for 9-17 animals in each group at each time. 


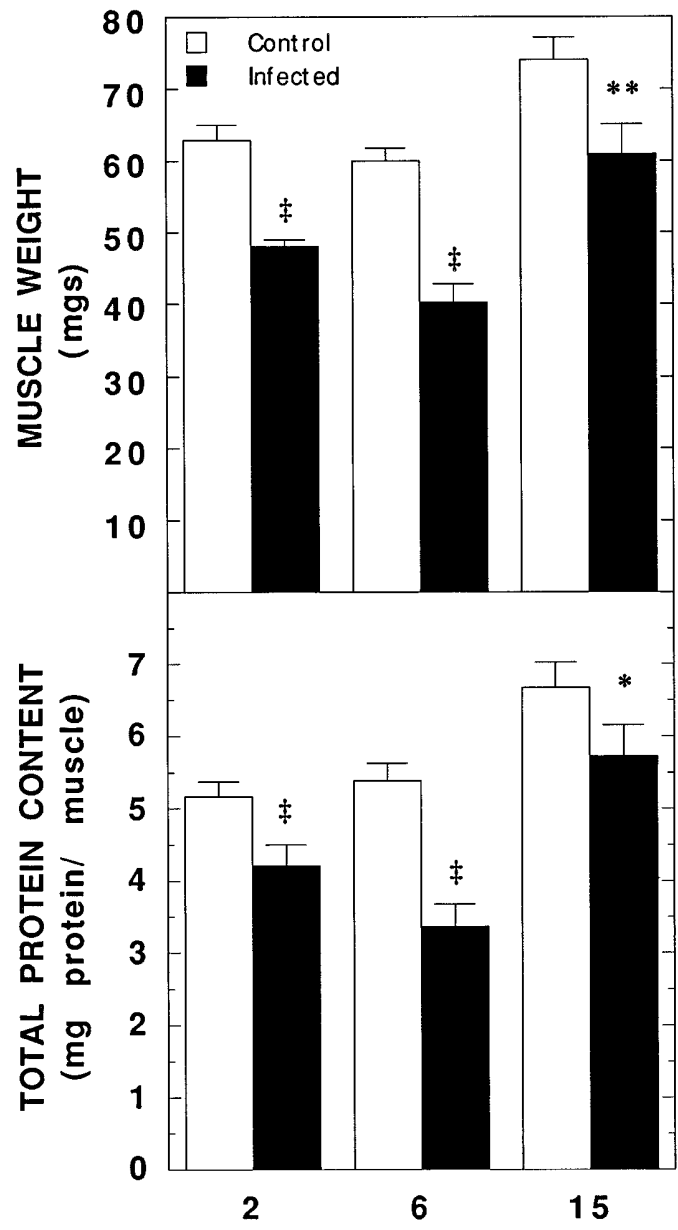

DAYS POST INFECTION

Fig. 4. Weight (top) and total protein content (bottom) of epitrochlearis muscle in infected and pair-fed control rats. Values shown are means \pm SE for 7- 25 animals in each group at each time. $* P<0.05$; $* * \mathrm{P}<0.01 ; \ddagger \mathrm{P}<0.001$ vs. control at same day postinfection.

ings were observed in the total protein content of the epitrochlearis (Fig. 4, bottom). Thetotal protein content/ muscle was reduced 24,37 , and $14 \%$ in the infected rats compared with muscles from control rats on days 2,6 , and 15 postinfection, respectively. Over the period from days 6 to 15 postinfection, the total protein content/ muscle was significantly increased from $3.4 \pm 0.3$ to $5.7 \pm 0.4 \mathrm{mg} / \mathrm{muscle}(\mathrm{P}<0.001)$ in infected rats. During the same time period, total protein content/ muscle in control rats increased from $5.4 \pm 0.3$ to $6.7 \pm$ $4 \mathrm{mg} / \mathrm{muscle}(\mathrm{P}<0.005)$.

The negative protein balance (basal condition; Table 2 ), as measured by the net release of tyrosine from incubated muscles, was significantly increased 2.4-fold 2 days after infection $(2.73 \pm 0.28 \mathrm{nmol} \mathrm{Tyr} \cdot \mathrm{mg}$ protein $\left.\mathrm{n}^{-1} \cdot \mathrm{h}^{-1}\right)$ compared with control $(1.13 \pm 0.07 \mathrm{nmol}$ $\mathrm{Tyr} \cdot \mathrm{mg}$ protein $\left.\mathrm{n}^{-1} \cdot \mathrm{h}^{-1}\right)$. Protein balance improved by $25 \%$ on day 6 postinfection $(2.04 \pm 0.34 \mathrm{nmol} \mathrm{Tyr} \cdot \mathrm{mg}$ protein ${ }^{-1} \cdot \mathrm{h}^{-1}$ ) but remained twofold more negative in muscles from infected rats compared with controls $\left(1.05 \pm 0.06 \mathrm{nmol}\right.$ Tyr $\cdot \mathrm{mg}$ protein $\left.\mathrm{n}^{-1} \cdot \mathrm{h}^{-1}\right)$. By day 15 postinfection, protein balance continued to improve in muscles from infected rats, returning to values ob- served in control animals ( $1.27 \pm 0.09$ vs. $1.5 \pm 0.14$ $\mathrm{nmol}$ Tyr $\cdot \mathrm{mg}$ protein $\left.\mathrm{n}^{-1} \cdot \mathrm{h}^{-1}\right)$.

To examine the possible mechanisms responsible for the enhanced negative protein balance of epitrochlearis after injection of bacteria, rates of protein synthesis and protein degradation were measured 2, 6, and 15 days postinfection (Figs. 5-7). The rate of muscle protein synthesis in infected rats 2 days postinfection was significantly decreased $(P<0.05)$ by $\sim 30 \%$ compared with their pair-fed controls (Fig. 5, basal). Six days after injection of bacteria, the rate of protein synthesis remained inhibited by $22 \%(P<0.005)$ compared with control rats (Fig. 6, basal). I n contrast to day 2 or 6 postinfection, the rate of protein synthesis was significantly increased on day 15 postinfection $(P<$ 0.05) compared with pair-fed control rats ( $\mathrm{Fig} .7$, basal).

The rate of protein degradation was significantly increased approximately twofold $(P<0.001) 2$ days after infection compared with pair-fed control rats (Fig. 5 , basal). The rate of degradation was not significantly decreased in infected rats on day 6 postinfection and remained elevated (70\%; $\mathrm{P}<0.001$ ) above values observed in muscles from control rats (Fig. 6, basal). By 15 days postinfection, the rate of protein degradation decreased relative to that observed at day 6 in infected rats. On day 15 postinfection, rates of protein degradation continued to diminish (Fig. 7, basal). There were no significant differences between control and infected rats at this time point.

Effect of insulin or IGF-I on protein turnover during infection. Table 2 shows the effects of addition of insulin $(2 \mathrm{nM})$ or IGF-I (10 nM) to the incubation medium on net protein balance in muscles from infected or pair-fed

Table 2. Effect of injection of bacteria on protein balance in epitrochlearis muscl eduring in vitro incubation: modulation by insulin or IGF-I

\begin{tabular}{|c|c|c|c|c|c|c|}
\hline \multirow{2}{*}{$\begin{array}{c}\text { Day } \\
\text { Postinfection }\end{array}$} & \multicolumn{3}{|c|}{ Control } & \multicolumn{3}{|c|}{ Infection } \\
\hline & Basal & +Insulin & +IGF-I & Basal & +Insulin & $+\mid G F-I$ \\
\hline \multirow{3}{*}{2} & 1.13 & 0.77 & 0.71 & 2.73 & 2.12 & 1.31 \\
\hline & $\begin{array}{c} \pm 0.07 \\
(12)\end{array}$ & $\begin{array}{c} \pm 0.06^{a} \\
(12)\end{array}$ & $\pm 0.04^{b}$ & $\begin{array}{l} \pm 0.28^{a} \\
(4)\end{array}$ & $\begin{array}{c} \pm 0.25^{c, d} \\
\text { (4) }\end{array}$ & $\pm 0.09^{e}$ \\
\hline & 1.05 & 0.50 & 0.46 & 2.04 & 1.16 & 0.65 \\
\hline \multirow[t]{3}{*}{6} & \pm 0.06 & $\pm 0.05^{a}$ & $\pm 0.02^{\mathrm{b}}$ & $\pm 0.34^{a}$ & $\pm 0.16^{c, f}$ & $\pm 0.06^{e, g}$ \\
\hline & (14) & (9) & (6) & (9) & (9) & (6) \\
\hline & 1.5 & 1.03 & & 1.27 & 0.99 & \\
\hline 15 & \pm 0.14 & $\pm 0.10^{\mathrm{b}}$ & ND & $\pm 0.09^{h}$ & $\pm 0.06^{f}$ & ND \\
\hline & (10) & (10) & & (9) & (8) & \\
\hline
\end{tabular}

Values are means \pm SE for no. in each group at each time given in parentheses. Protein balance is measured by net nanomoles of tyrosine released per milligram of protein per hour. ND, not determined. Muscles were excised and incubated as described in METHODS. Basal protein balance results were obtained in absence of hormones in incubation medium. Insulin or insulin-like growth factor I (IGF-I) was added to give a final concentration of 2 or $10 \mathrm{nM}$ in the medium, respectively. Basal: (ANOVA $\mathrm{F}=10.85, \mathrm{P}<0.001$ ); + Insulin: (ANOVA $\mathrm{F}=19.76, \mathrm{P}<0.001$ ); +IGF-I: (ANOVA $\mathrm{F}=16.447, \mathrm{P}<0.001$ ). ${ }^{\text {a }} \mathrm{P}<$ $0.01 ;{ }^{b} \mathrm{P}<0.05$ vs. control, basal at same time point. ${ }^{\mathrm{C} P}<0.01 \mathrm{vs}$. control, +insulin at same time point. $\mathrm{d} P<0.001$ vs. day 6 or 15 infection, +insulin. ep $<0.05$ vs. infection, basal or infection, + insulin at same time point; ${ }^{f} \mathrm{P}<0.05$ vs. infection, basal at same time; ${ }^{\mathrm{P}}<0.05$ vs. day 2 infection, +IGF-I. ${ }^{\mathrm{h} P}<0.05$ vs. day 2 or 6 infection, basal. 


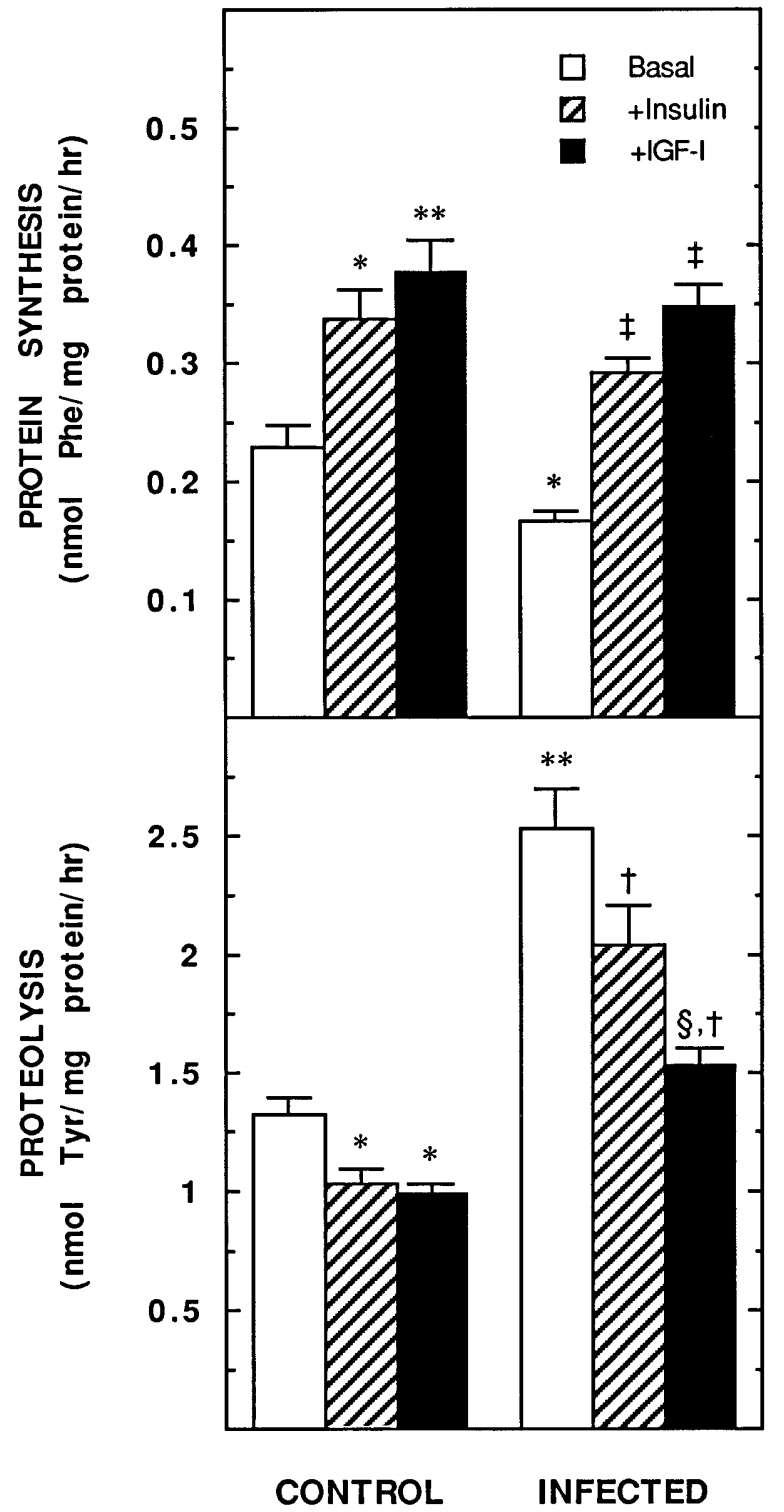

Fig. 5. Rates of protein synthesis (top) and proteolysis (bottom) 2 days after injection of $E$. coli in infected and pair-fed control rats: effects of insulin and IGF-I. E pitrochlearis muscles from infected and pair-fed control rats (as indicated) were excised and incubated in vitro 2 days after injection of bacteria as described in MATERIALS AND METHODS in presence of insulin or IGF-I or in their absence. Insulin or IGF-I was added to give final concentrations of 2 and $10 \mathrm{nM}$, respectively, in incubation medium. Rates of protein synthesis and protein degradation were measured as described Fig. 1. Values shown are means \pm SE for 5-14 muscles in each group. Protein synthesis: ANOVA $\mathrm{F}=25.68, \mathrm{P}<0.001$. Protein degradation: ANOVA $\mathrm{F}=$ 23.58, $\mathrm{P}<0.001$. *P $<0.05$; ** $\mathrm{P}<0.005$ vs. control, basal; $\dagger \mathrm{P}<$ 0.001 vs. infected, basal; $¥ P<0.001$ vs. control, +insulin or control, + IGF -I ; §P $<0.05$ vs. infected, basal and infected, +insulin.

control rats. In control rats, addition of either insulin or IGF-I to theincubation medium significantly depressed the net release of tyrosine from epithrochlearis by $30-50 \%$ compared with basal conditions at each of the days investigated. Both hormones were equally effective in limiting the negative protein balance. There were no significant differences between insulin and IGF-I with respect to their ability to inhibit net tyrosine release.
In contrast to control, muscles from infected rats responded differently to insulin or IGF-I (Table 2). The negative protein balance $(2.12 \pm 0.25 \mathrm{nmol}$ Tyr $\cdot \mathrm{mg}$ protein $\left.n^{-1} \cdot h^{-1}\right)$ in the presence of insulin was not significantly reduced on day 2 postinfection compared with rates obtained under basal conditions $(2.78 \pm 0.28$ $\mathrm{nmol} \mathrm{Tyr} \cdot \mathrm{mg}$ protein $\mathrm{n}^{-1} \cdot \mathrm{h}^{-1}$ ). By 6 days postinfection, the inhibition of proteolysis by insulin was greater than on day 2 postinfection. The negative protein balance in

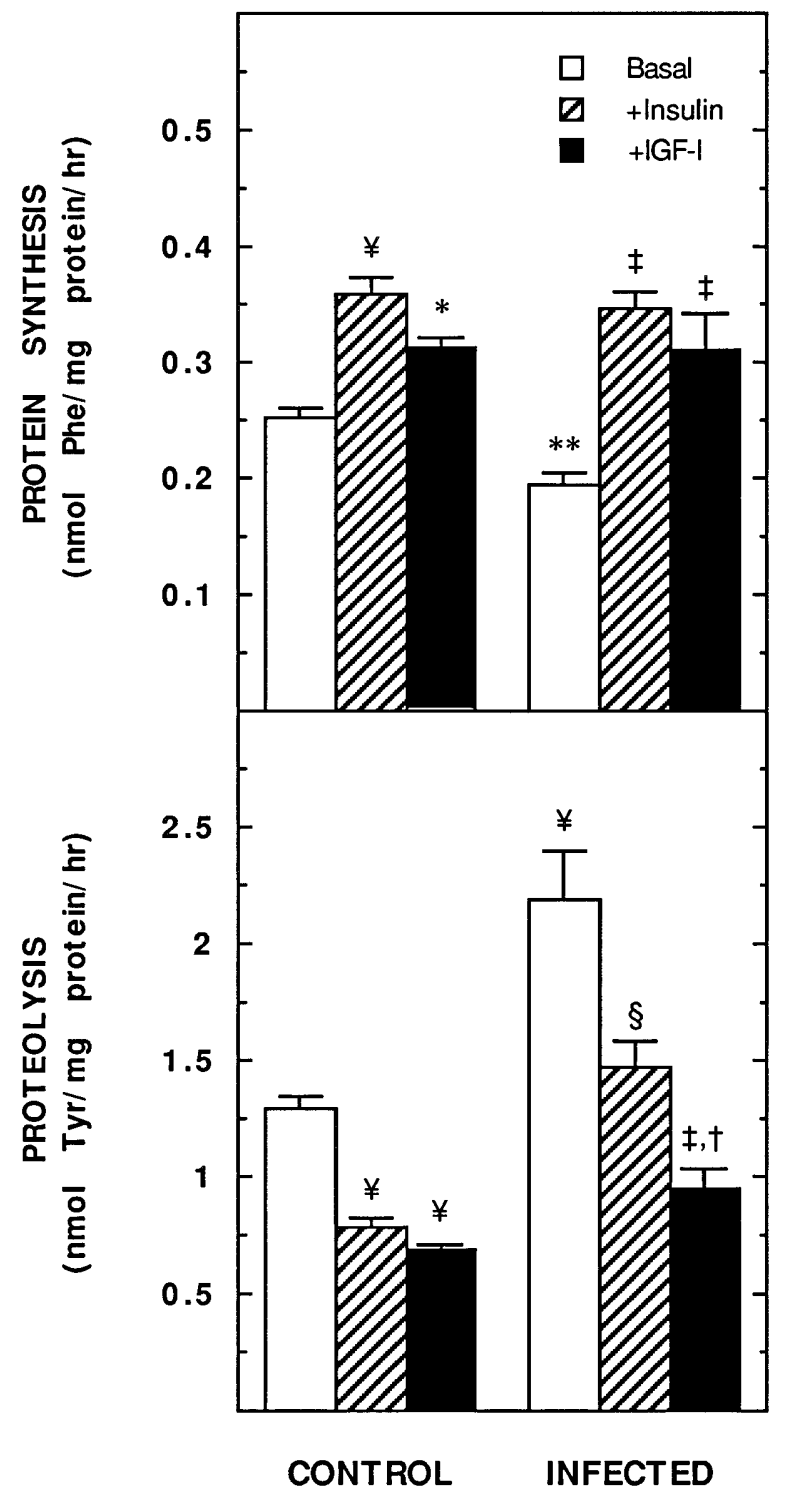

Fig. 6. Rates of protein (top) synthesis and proteolysis (bottom) 6 days after injection of $\mathrm{E}$. coli in infected and pair-fed control rats: effects of insulin and IGF-I. E pitrochlearis muscles from infected and pair-fed control rats (as indicated) were excised and incubated in vitro 6 days after injection of bacteria as described in MATERIALS AND METHODS in presence of insulin or IGF-I or in their absence. Insulin or IGF-I was added to give a final concentration of 2 and $10 \mathrm{nM}$, respectively, in incubation medium. Rates of protein synthesis and protein degradation were measured as described Fig. 1. Values shown are means \pm SE for 5-18 muscles in each group. Protein synthesis: ANOVA $\mathrm{F}=17.57, \mathrm{P}<0.001$. Protein degradation: ANOVA $\mathrm{F}=$ 23.25, $\mathrm{P}<0.001$. $* \mathrm{P}<0.05$; ** $\mathrm{P}<0.005 ; ¥ \mathrm{P}<0.001$ vs. control, basal; $¥ \mathrm{P}<0.005$ vs. infected, basal; $† \mathrm{P}<0.05$ vs. infected, + insulin; $\S \mathrm{P}<0.005$ vs. infected, basal, and control, +insulin 


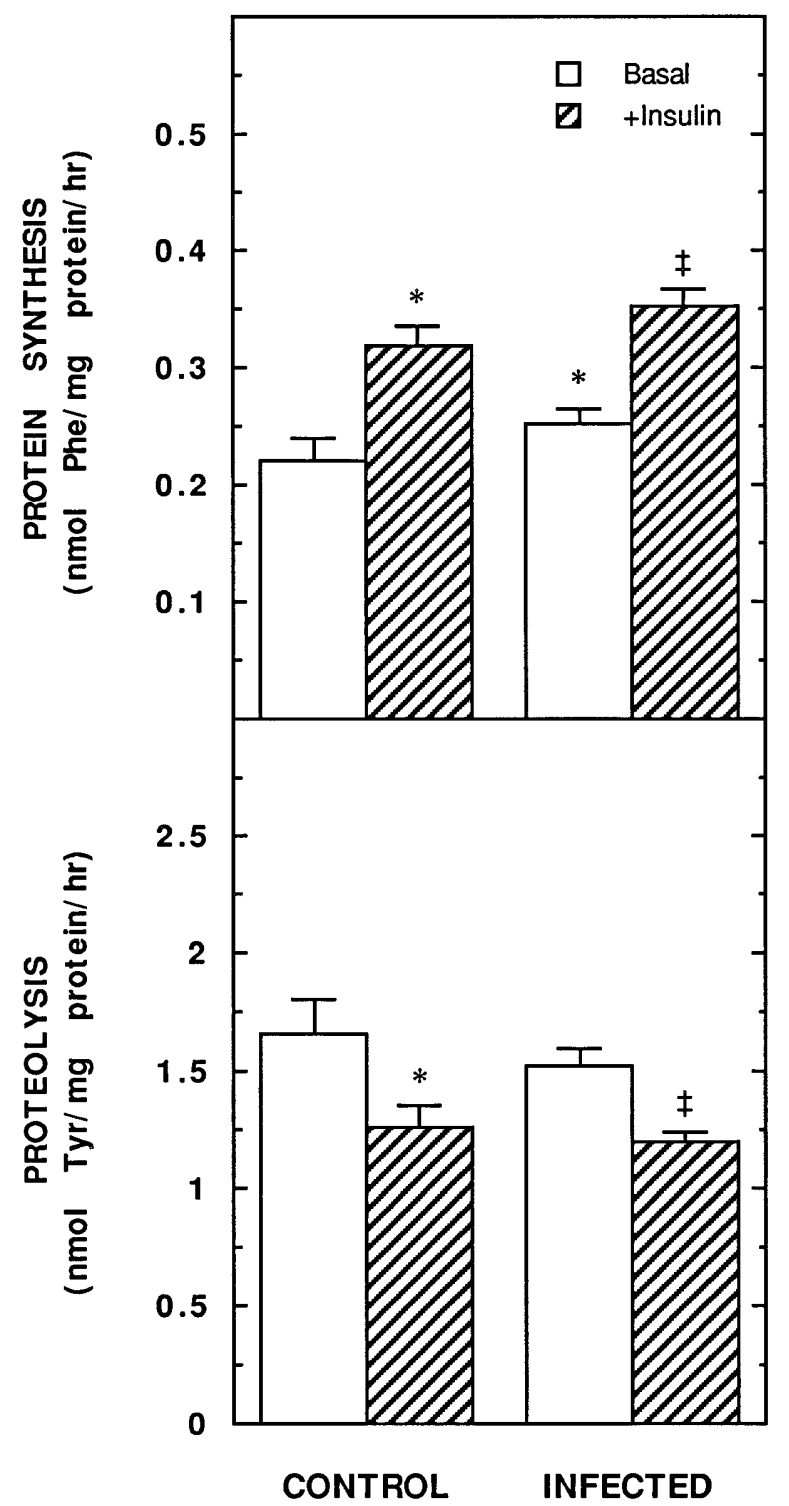

Fig. 7. Rates of protein synthesis (top) and proteolysis (bottom) 15 days after injection of $\mathrm{E}$. coli in infected and pair-fed control rats: effects of insulin. Epitrochlearis muscles from infected and pair-fed control rats (as indicated) were excised and incubated in vitro 15 days after injection of bacteria as described in MATERIALS AND METHODS in presence or absence of insulin. Insulin was added to give a final concentration of $2 \mathrm{nM}$ in incubation medium. Rates of protein synthesis and protein degradation were measured as described Fig. 1 . Values shown are means \pm SE for 8-10 muscles in each group. Protein synthesis: ANOVA F $=22.22, \mathrm{P}<0.001$. Protein degradation: ANOVA $\mathrm{F}=4.49, \mathrm{P}<0.01 . * \mathrm{P}<0.05$, control, basal; $\ddagger \mathrm{P}<0.05$ vs. infected, basal.

presence of insulin (1.16 $\pm 0.16 \mathrm{nmol} \mathrm{Tyr} \cdot \mathrm{mg}$ protein $n^{-1} \cdot h^{-1}$ ) was reduced $43 \%$ relative to the basal state in infected rats $(2.04 \pm 0.34 \mathrm{nmol} \mathrm{Tyr} \cdot \mathrm{mg}$ protein $-1 \cdot h^{-1}$ ). At both days, the negative protein balance remained elevated twofold relative to control muscle incubated in presence of insulin. By 15 days postinfection, insulin significantly reduced net protein balance by $22 \%$. Furthermore, no differences between control and infected rats were observed after incubation with insulin. In contrast to the effects of insulin, addition of IGF-I to incubation medium resulted in a significant $50 \%$ reduction in the negative protein balance 2 days postinfection. However, net protein balance remained el evated relative to muscles from control rats incubated in the presence of IGF -I. By 6 days postinfection, the protein balance was further reduced in muscles incubated with I GF-I compared with day 2. The rel ease of tyrosine was not significantly different from that observed in controls.

To further characterize the processes responsible for changes in the protein balances, rates of protein synthesis and proteolysis in the presence of insulin or IGF-I were measured. After infection, the rate of protein synthesis in muscles from either control or infected rats was significantly stimulated by addition of insulin or IGF-I to the medium at each of the time points investigated (Figs. 5-7). There were no significant differences between control and infected rats with respect to the rate of protein synthesis in the presence of insulin or IGF-I. Furthermore, there were no significant differences in the maximal rate of protein synthesis after incubation with either insulin or IGF-I. Thus muscles from each group responded in a similar manner to addition of insulin or IGF-I.

Rates of proteolysis were significantly reduced after incubation of muscles with insulin or IGF-I in control rats at each of the time points examined (Figs. 5-7). There were no apparent differences between insulin and IGF-I with respect to their ability to inhibit protein degradation in epitrochlearis from control rats.

We next examined whether insulin and IGF-I were equally effective in reducing proteolysis in muscle from rats after injection with live bacteria. Unlike muscles from control rats, protein degradation was not significantly decreased in muscle from infected rats 2 days postinfection incubated in the presence of insulin (Fig. 5). The rate of protein degradation in muscle of infected rats incubated with insulin remained twofold higher than in pair-fed control rats. In contrast to insulin, IGF-I caused an $\sim 40 \%$ decrease in the rate of protein degradation in muscles from infected rats $(P<0.01) 2$ days after infection (Fig. 5). However, the rate of protein degradation in muscles from infected rats remained significantly elevated (54\%) compared with pair-fed control rats incubated with IGF-I (P < 0.001).

On day 6 postinfection, the rate of protein degradation was significantly decreased $33 \%(P<0.05)$ in epitrochlearis incubated in the presence of insulin compared with muscles from infected rats incubated in the hormone's absence (Fig. 6). However, the rate of protein degradation in muscles from infected rats remained approximately twofold higher than that observed in muscles from control rats incubated under identical conditions. On the other hand, IGF-I reduced protein degradation $\sim 55 \%$ in muscles from infected rats (Fig. 6). The rate of protein degradation in presence of IGF-I was significantly reduced $35 \%$ compared with muscles incubated in the presence of insulin. The diminution of proteolysis in the presence of IGF-I was sufficient, so that no significant differences in the rate of protein degradation were observed between infected and control rats. 
By day 15 postinfection, proteolysis in muscles from rats injected with bacteria was reduced to the same extent as control in the presence of insulin (Fig. 7). No significant differences between control and infected rats were observed. Because IGF-I completely restored protein balance to values observed in control rats by 6 days postinfection, the effect of I GF-I on protein synthesis and degradation was not tested at 15 days after injection of bacteria.

\section{DISCUSSION}

Results from the present studies indicate that fundamental defects in the regulation of protein synthesis and protein degradation in skeletal muscle occur days after injection of live E. coli. The dyshomeostasis was manifested by an inhibition of protein synthesis and stimulation of protein degradation that persisted for up to 1 wk postinfection. Protein synthesis was stimulated by insulin or IGF-I to the same extent in infected rats compared with controls. In contrast, proteolysis in infected rats was limited to a lesser degree by insulin compared with IGF-I. Comparisons between control and infected rats were made under similar nutritional conditions so that the differences observed can be ascribed to the host's response to the bacterial insult rather than nutritional deficiency. Because noninfected, control animals consumed the same amount of food as septic rats, the derangements in protein synthesis and proteolysis after injection of live bacteria are independent of and in addition to those associated with reduced food intake. The persistence of these infectioninduced changes in protein synthesis and protein degradation compared with pair-fed control rats demonstrates the response to be a direct consequence of the infection process rather than an indirect effect via alterations in food intake.

The host's response to sepsis is characterized by three phases $(3,4,17)$. The first phase, which lasts for up to 2 days, is characterized by initiation of infection. A predominant feature during this period is anorexia $(1,3,17,33)$, with rats injected with bacteria consuming only $\sim 30 \%$ of the normal food intake during this period. Moreover, infected rats exhibited a greater loss of muscle mass than pair-fed control rats. Therefore, although anorexia may contribute, it is not sufficient by itself to account for the loss of skeletal muscle mass during sepsis. The loss of protein from skeletal muscle in infected rats results from a $27 \%$ reduction in protein synthesis and a $91 \%$ acceleration of protein degradation relative to pair-fed control rats.

The second phase of the host's response to sepsis is associated with a stable, hypermetabolic condition whereby despite adequate nutrient intake, normal growth or positive nitrogen balance is not achieved ( 1 , $4,17,32,33)$. In the present set of investigations, the skeletal muscle mass is reduced relative to pair-fed controls 6 days after injection of bacteria. Protein balance improves relative to the anorexic phase but remains twofold elevated compared with noninfected rats. During the hypermetabolic phase, protein synthesis is inhibited by $22 \%$ and protein degradation is stimulated by $70 \%$. An inhibition of protein synthesis of a similar magnitude has also been reported in muscles of rats with a chronic septic abscess $(4,16-18,32)$ and septic patients in vivo $(3,23)$. Proteolysis is accelerated in muscles from septic patients, indicating that protein degradation remains el evated during the chronic, hypermetabolic phase of sepsis (23). The results obtained in the present study are consistent with these reports concerning the long-term effect of sepsis on protein turnover both in septic patients and animals.

During the recovery phase (day 15 postinfection), body weight and muscle mass increase compared with the hypermetabolic phase. From days 6 to 15 postinfection, the total protein content/muscle was significantly increased by $70 \%$ (2.36 mg protein/muscle) in infected rats. During the sametime period, total protein content/ muscle in control rats increased by $24 \%$ (1.29 mg protein/muscle). Thus, by day 15 postinfection, the protein balance in incubated muscles was not significantly different between control and infected rats. Rates of protein synthesis were actually augmented in infected animals compared with control, whereas protein degradation returned to values observed in noninfected animals. Accretion of muscle mass during the recovery phase resulted from a decreased rate of protein degradation and an increase in protein synthesis relative to the hypermetabolic phase of sepsis (day 6).

Insulin resistance is defined as a less than normal response to a dose of insulin (21). Muscles from infected rats showed a markedly reduced response to the anabolic actions of insulin on net protein balance during the anorexic phase of sepsis. During the hypermetabolic phase, the ability of insulin to affect protein balance was partially restored, but the negative protein balance remained el evated twofold relative to controls. Improvement in the protein balance was greater in muscles incubated in the presence of IGF-I than insulin after infection. During the anorexic phase, negative protein balance was reduced $50 \%$ in the presence of IGF-I. This observation is in contrast to insulin, for which no significant effect on negative protein balance was observed. On day 6 postinfection, protein balance in muscles incubated with IGF-I was improved $40 \%$ relative to muscles from septic rats incubated in the presence of insulin. Furthermore, the protein balance was not different in infected rats incubated with IGF-I compared with controls.

Thechanges in the protein balance are consequence of infection-induced derangements in protein synthesis and degradation. Protein synthesis in muscles from infected rats incubated in the presence of insulin was enhanced during each of the phases examined. The maximal responsiveness of protein synthesis to stimulation by insulin was not altered in infected rats compared with controls. Like insulin, IGF -I stimulated protein synthesis at each of the time points examined. Furthermore, the maximal stimulation of protein synthesis by IGF-I was not different between control and infected rats. Therefore no evidence of a resistance to insulin- or IGF-I-induced stimulation of protein synthesis was observed after injection of a single strain of 
bacteria. Similar conclusions concerning the responsiveness of protein synthesis to stimulation by insulin were observed after acute (16 h) peritonitis by Hasselgren and co-workers (11, 12). However, a chronic (5 days), hypermetabolic intra-abdominal abscess sepsis was associated with a profound insulin resistance, even at pharmacological doses of the hormone (16). The reasons for this apparent discrepancy are unclear but may reflect differences in the host's response to intraabdominal polyclonal septic abscess vs. the intravenous injection of a single bacterial strain.

In contrast to protein synthesis, the ability of insulin to decrease proteolysis was severely curtailed for periods up to $48 \mathrm{~h}$ after injection of bacteria. This observation suggests that the relative resistance of proteolysis to insulin, described in extensor digitorum longus during acute $(16 \mathrm{~h})$ peritonitis $(11,12)$, persists for at least $48 \mathrm{~h}$ after injection of bacteria. In the present studies, the ability of insulin to reduce proteolysis was augmented in infected rats during the chronic hypermetabolic phase relative to the anorexic period. However, proteolysis remained elevated relative to noninfected animals. Caution must be exercised in extrapolating our results to conclude that protein degradation was totally insensitive to insulin during the anorexic and hypermetabolic phases in the response to infection. Although we have not defined a dose-response relationship between protein degradation and insulin in incubated muscles from infected rats, previous studies in fed, infected animals have shown that proteolysis is less sensitive to the antiproteolytic effects of insulin even at pharmacological (100 nM) doses of insulin (33).

There are no other reports concerning the effect of IGF-I on muscle protein degradation during sepsis. In the present study, incubation with IGF-I was able to partially inhibit proteolysis during the anorexic phase. Despite the ability of IGF-I to reduce proteolysis, the rate of protein degradation remained $50 \%$ higher than values observed in muscles from control animals. IGF-I caused a further inhibition of proteolysis during the hypermetabolic phase after infection. During this period, proteolysis in the muscles from infected and control rats did not differ. Hence, muscle from infected rats appeared more responsive to the antiproteolytic effects of IGF-I compared with insulin. The mechanisms responsible for the differential responses to insulin and IGF-I in muscles from infected rats remain unknown. Unlike insulin, the plasma concentrations of IGF-I are reduced during sepsis (19) in animals or after infusion of GH in septic patients (5). Maintenance of the plasma I GF -I concentrations during chronic sepsis prevented the inhibition in muscle protein synthesis (19).

Several lines of evidence argue against the differences in skel etal muscle protein synthesis and degradation between control and infected rats being a consequence of decreased viability of the preparation over the course of the incubation period. First, protein synthesis in muscles from infected rats is stimulated to the same extent by insulin or IGF-I as muscles from control rats. Moreover, the magnitude of the stimula- tion of protein synthesis in control rats by insulin is similar to previous reports $(24,25)$. Second, lactate production, although el evated in muscles from infected rats, remains constant over the 3 -h incubation period in epitrochlearis muscle from either control or infected rats (31). Third, the high-energy phosphate contents (ATP + creatine phosphate) in muscle are not significantly reduced after incubation for periods up to 240 min in epitrochlearis muscle weighing $\sim 150 \mathrm{mg}$ (twice mass of muscles used in present study) under similar conditions (Savary, I., D. Dardevet, and J . Grizard, unpublished data). Fourth, several investigators have suggested that the stimulation of proteolysis after infection occurs by an energy-dependent pathway (26, 33). Thus decreased viability and loss of energy would lead to a diminution, not a stimulation of proteolysis in muscles from infected rats.

In summary, infection causes fundamental defects in skeletal muscle protein synthesis and proteolysis independent of the nutritional state of the animal. The impairment in protein synthesis is observed as early as 2 days postinfection and is maintained for at least 6 days. However, by 15 days postinfection, protein synthe sis was actually enhanced in septic rats compared with control. Inclusion of insulin or IGF-I during in vitro incubation can overcome the infection-induced inhibition in protein synthesis. On the other hand, protein degradation was greatly enhanced after injection of bacteria. The stimulated rate of proteolysis after infection persisted for at least 6 days but returned to values observed in control rats by day 15 postinfection. The ability of insulin to inhibit proteolysis was severely blunted, indicating that this process exhibits an insulin resistance after infection. However, proteolysis in muscles from infected rats appeared more responsiveto IGF-I than insulin during both the anorexic and hypermetabolic phases of the host response to injection of bacteria. The ability of insulin or IGF-I to suppress proteolysis becomes enhanced with time as the effects of infection wane. Because the present experiments were performed in incubated muscles, the effects of insulin or IGF-I on protein synthesis or proteolysis are the direct effect of these hormones on epitrochlearis and are not related to systemic perturbations secondary to infusion of the hormones in vivo. The differential response to IGF-I vs. insulin may reflect how infection alters the dose-response curves for each individual hormone. Furthermore, it is unknown whether the component of proteolysis dysregulated by infection is the same component that responds to the hormones. However, the defect does not appear to be a generalized phenomenon in insulin or IGF-I signaling pathways, because rates of protein synthesis measured in the same musdes are responsive to stimulation by these hormones.

The authors thank C. Sornet for expert technical assistance.

This study was supported by Clintec Technologies, France, Institut National de la RechercheAgronomique, and National Institute of General Medical Sciences Grant GM-39277.

Address for reprint requests: T. C. Vary, Dept. of Cellular and Molecular Physiology, Penn State University College of Medicine, Hershey, PA 10733.

Received 29J anuary 1998; accepted in final form 10 J une 1998. 


\section{REFERENCES}

1. Breuille, D., M. C. Farge, R. Rose, M. Arnal, and C. Obled. Pentoxyfylline decreases the body weight loss and muscle protein wasting characteristic of sepsis. Am. J . Physiol . 265 (Endocrinol. Metab. 28): E660-E666, 1993.

2. Breuille, R. Rose, M. Arnal, D. C. Melin, and C. Obled. Sepsis modifies the contribution of different organs to wholebody protein synthesis in rats. Clin. Sci. (Colch.) 86: 663-669, 1994.

3. Cooney, R., S. R. Kimball, and T. C. Vary. Regulation of skeletal muscle protein turnover during sepsis: mechanisms and mediators. Shock 7: 1-7, 1997.

4. Cooney, R., E. Owens, C. J urasinski, K. Gray, J . Vannice, and T. Vary. Interleukin-1 receptor antagonist prevents sepsisinduced inhibition of protein synthesis. Am. J. Physiol. 267 (Endocrinol. Metab. 30): E636-E641, 1994.

5. Dahn, M. S., M. P. Lange, and L. A. J acobs. Insulin-like growth factor-1 production is inhibited in human sepsis. Arch. Surg. 123: 1409-1414, 1988.

6. Dardevet, D., C. Sornet, D. Attaix, V. E. Baracos, and J . Grizard. Insulin-like growth factor-I and insulin resistance in skeletal muscle of adult and old rats. Endocrinology 134: 14751484, 1994.

7. Dardevet, D., C. Sornet, T. Vary, and J . Grizard. Phosphotidylinositol 3-kinase and p70 S6 kinase participate in the regulation of protein turnover in skeletal muscle by insulin and insulin-like growth factor I. Endocrinology 137: 4089-4094, 1996.

8. Dickerson, R. N., C. B. Manzo, S. L. Charland, R. G. Settle, T. P. Stein, D. A. Kuhl, and J .-J . Rajter. The effects of insulin-like growth factor-1 on protein metabolism and hepatic response to endotoxin in parenterally fed rats. J . Surg. Res. 58: 260-266, 1995

9. Fang, C. H., B. G. Li, J . Howard, J . E. Fischer, and P.-O. Hasselgren. Cytokines block effects of insulin-like growth factor-I (IGF-I) on glucose uptake and lactate production in skel etal muscle but do not influence IGF-I-induced changes in protein turnover. Shock 8: 362-367, 1997.

10. Fryburg, D. A. Insulin-like growth factor I exerts growth hormone and insulin-like actions on human muscle protein metabolism. Am. J . Physiol. 267 (Endocrinol. Metab. 30): E331E336, 1994.

11. Hasselgren, P. O., J . H. J ames, D. W. Benson, M. HallAngeras, U. Angeras, D. T. Hiyama, S. Li, and J . E. F ischer. Total and myofibrillar protein breakdown in different types of rat skeletal muscle: effects of sepsis and regulation by insulin. Metabolism 38: 634-640, 1989.

12. Hasselgren, P. O., B. W. Warner, J . H. J ames, H. Takehara, and $\boldsymbol{J}$. E. Fischer. Effect of insulin on amino acid uptake and protein turnover in skel etal muscle from septic rats. Evidence for insulin resistance of protein breakdown. Arch. Surg. 122: 228233, 1987.

13. J acob, R., X. Hu, D. Niederstock, S. Hasan, P. H. McNulty, R. S. Sherwin, and L. H. Young. IGF-I stimulation of muscle protein synthesis in the awake rat; permissive role of insulin and amino acids. Am. J . Physiol. 270 (Endocrinol. Metab. 33): E60E66, 1996.

14. J ahoor, F., R. F. Shengraw, H. Miyoshi, and R. R. Wolfe. Role of insulin and glucose oxidation in mediating the protein catabolism of burns and sepsis. Am. J . Physiol 257 (Endocrinol. Metab. 20): E 323-E331, 1989.

15. J epson, M. M., J . M. Pell, P. C. Bates, and D. J . Millward. The effects of endotoxemia on protein metabolism in skeletal muscle and liver of fed and fasted rats. Biochem. J . 235: 329-336, 1986.

16. J urasinski, C., K. Gray, and T. C. Vary. Modulation of skeletal muscle protein synthesis by amino acids and insulin during sepsis. Metabolism 44: 1130-1138, 1995.

17. J urasinski, C. V., L. Kilpatrick, and T. C. Vary. Amrinone prevents muscle protein wasting during chronic sepsis. Am. J. Physiol. 268 (Endocrinol. Metab. 31): E491-E500, 1995.

18. J urasinski, C. V., and T. C. Vary. Insulin-like growth factor I accelerates protein synthesis during sepsis. Am. J . Physiol. 269 (Endocrinol. Metab. 32): E977-E981, 1995.
19. Lang, C. H., J . Fan, R. Cooney, and T. C. Vary. I L-1 receptor antagonist attenuates sepsis-induced alterations in IGF system and protein synthesis. Am. J. Physiol. 270 (Endocrinol. Metab. 33): E430-E 437, 1996.

20. O'Sullivan, U., P. D. Gluckman, B. H. Breier, S. Woodhall, R. A. Siddiqui, and S. N. McCutcheon. Insulin-like growth factor I (IGF-I) reduces weight loss in mice during starvation. Endocrinology 125: 2793-2794, 1989.

21. Peraldi, P., G. S. Hotamisligil, W. A. Buurman, M. F. White, and B. M. Speigelman. Tumor necrosis factor (TNF)- $\alpha$ inhibits insulin signaling through stimulation of the p55 receptor and activation of sphingomyelinase. J. Biol. Chem. 271: 1301813022, 1996.

22. Russell-J ones, D. L., A. M. Umpleby, T. R. Hennessey, S. B. Bowes, F. Shojaee-Moradies, K. D. Hopkins, N. C. J ackson, J . M. Kelly, R. H. J ones, and P. H. Sonksen. Use of a leucine clamp to demonstrate that IGF-I actively stimulates protein synthesis in normal humans. Am. J . Physiol. 267 (Endocrinol. Metab. 30): E591-E 598, 1994.

23. Sjolin, J ., H. Stjrnstrom, G. Friman, J . Larsson, and J . Wharen. Total and net muscle protein breakdown in infection determined by amino acid effluxes. Am. J . Physiol. 258 (Endocrinol. Metab. 21): E856-E863, 1990.

24. Stirewalt, W. S., and R. B. Low. Effects of insulin on protein turnover in rat epitrochlearis muscle. Biochem. J . 210: 323-330, 1983.

25. Stirewalt, W. S., R. B. Low, and J. M. Slaiby. Insulin sensitivity and responsi veness of epitrochlearis and sol eus muscle from fed and starved rats. Biochem. J . 227: 355- 362, 1985.

26. Tiao, G., M. Lieberman, J . E. Fischer, and P. O. Hasselgren. Intracellular regulation of protein degradation during sepsis is different in fast- and slow-twitch muscle. Am. J. Physiol. 272 (Regulatory IntegrativeComp. Physiol. 41): R849-R856, 1997.

27. Tomas, F. M., S. E. Knowles, P. C. Owens, C. S. Chandler, G. L. Francis, L. C. Read, and F. J . Ballard. Insulin-like growth factor-I (IGF-I) and especially IGF-I variants are anabolic in dexamethasone-treated rats. Biochem. J . 282: 91-97, 1992.

28. Tomas, F. M., S. E. Knowles, P. C. Owens, L. C. Read, C. S. Chandler, S. E. Gargosky, and F.J . Ballard. I ncreased weight gain, nitrogen retention, and muscle protein synthesis following treatment of diabetic rats with insulin-like growth factor (IGF)-I and des(1-3)IGF-I. Biochem. J . 276: 547-554, 1991.

29. Tischler, M., and J. M. Fagan. Response to trauma and protein, amino acid, and carbohydrate metabolism in injured and uninjured rat skel etal muscle. Metabolism 32: 853- 868, 1983.

30. Vary, T. C. Sepsis-induced alterations in pyruvate dehydrogenase complex activity in rat skeletal muscle: effect on plasma lactate. Shock 6: 89-94, 1996.

31. Vary, T. C., D. Dardevet, C. Obled, C. Pouyet, D. Brueille, and J . Grizard. Modulation of skel etal muscle lactate metabolism following bacteremia by insulin or insulin-like growth factor I: effects of pentoxifylline. Shock 7: 423-438, 1997.

32. Vary, T. C., and S. R. Kimball. Sepsis-induced changes in protein synthesis: differential effects on fast- and slow-twitch muscles. Am. J . Physiol. 262 (Cell Physiol. 31): C1513-C1519, 1992.

33. Voisin, L., D. Breuille, L. Combaret, C. Pouyet, D. Taillandier, E. Aurousseau, C. Obled, and D. Attaix. Muscle wasting in a rat model of long-lasting sepsis results from activation of Iysosomal, $\mathrm{Ca}^{2+}$-activated, and ubiquitin-proteasome proteolytic pathways. J . Clin. Invest. 97: 1610-1617, 1996.

34. Wilmore, D. W. Catabolic illness-strategies for enhancing recovery. N. Engl. J . Med. 325: 695-802, 1991.

35. Woofson, A. M. J ., R. V. Heatley, and S. P. Allison. Insulin to inhibit protein catabolism after injury. N. Engl. J. Med. 300: 14- 17, 1979.

36. Zamir, O., P. O. Hasselgren, S. L. Kunkel, J . A. Frederick, T. Higashiguchi, and J . E. Fischer. Evidence that tumor necrosis factor participates in the regulation of proteolysis during sepsis. Arch. Surg. 127: 170-174, 1992.

37. Zamir, O., P. O. Hasselgren, W. O'Brien, R. C. Thompson, and J . E. Fischer. Muscle protein breakdown during endotoxemia in rats after treatment with interleukin-1 receptor antagonist (IL-1ra). Ann. Surg. 216: 381-386, 1992. 